\title{
BIOCIDE TREATMENT OF PONDS IN SCOTLAND TO ERADICATE SIGNAL CRAYFISH
}

\author{
S. PEAY (1), P. D. HILEY (1), P. COLLEN (2), I. MARTIN (3)
}

(1) Scott Wilson, The Design Innovation Centre, 46 The Calls, Leeds, LS2 7EY, UK. E-Mail: stephanie@crayfish.org.uk

(2) Fisheries Research Services, Freshwater Laboratory, Faskally, Pitlochry, PH16 5LB, UK.

(3) Scottish Natural Heritage, 16 Rubislaw Terrace, Aberdeen, AB1 1XE, UK.

Reçu le 20 september 2005

Accepté le 2 janvier 2006

Received September 20, 2005

Accepted January 02, 2006

\begin{abstract}
This trial aimed to eradicate illegally introduced signal crayfish Pacifastacus leniusculus in the North Esk catchment, Scotland. Sites treated were (1) an isolated gravel-pit (c. 9,000 $\left.\mathrm{m}^{3}\right)$, with crayfish present for 6 years; (2) three dammed ponds, (c. $5,000 \mathrm{~m}^{3}$ ) and (3) a leaking, offline pond (c. 6,000 $\mathrm{m}^{3}$ ), with crayfish for two years. Preliminary toxicity tests with substrate present indicated doses. Treatment at sites (1) and (2) (in October 2004 , water temperature $13^{\circ} \mathrm{C}$ ) comprised deoxygenation with sodium sulphite to stimulate emergence, then application of natural pyrethrum (Pyblast). Exposed margins were sprayed with Pyblast to prevent escapes. Crayfish mortality was high, but one survivor was seen after 5 days. Pyblast was applied from a tank with $\mathrm{Na}_{2} \mathrm{SO}_{3}$ residue, which subsequent investigation indicated reduced Pyblast below the target $0.1 \mathrm{mg} \mathrm{l}^{-1}$. Site (1) was re-treated (end October, target $0.15 \mathrm{mg} \mathrm{l}^{-1}$ Pyblast, no $\mathrm{Na}_{2} \mathrm{SO}_{3}, 9^{\circ} \mathrm{C}$ ). Mortality was confirmed using caged crayfish. Prior to treatment at site (2), throughflow was stopped and fish removed. Biomonitoring was carried out with freshwater shrimps Gammarus in the adjacent watercourse. Treatment of site (3) (December, target $0.2 \mathrm{mg} \mathrm{l}^{-1}, 4^{\circ} \mathrm{C}$ ) necessitated continuous back-pumping of leakage for a 2-week recovery period to avoid contamination of the river downstream. Caged crayfish took up to 5 days for $100 \%$ mortality. No crayfish were found in a summer survey after the treatments with Pyblast alone, but were caught in the ponds with $\mathrm{Na}_{2} \mathrm{SO}_{3}$ pre-treatment. Monitoring is required for 2-5 years.
\end{abstract}

Key-words: Pacifastacus leniusculus, eradication, biocide, ponds, natural pyrethrum.

\section{ÉRADICATION DE L'ÉCREVISSE SIGNAL DANS LES ÉTANGS ÉCOSSAIS PAR TRAITEMENTS BIOCIDIQUES}

\section{RÉSUMÉ}

Cet essai avait pour but d'éliminer l'écrevisse signal (Pacifastacus leniusculus) introduites illégalement dans le nord du bassin de l'Esk, en Ecosse. Les sites d'expérimentation furent une sablière isolée $\left(\mathrm{ca} .9000 \mathrm{~m}^{3}\right.$ ), trois étangs de retenue (ca. $5000 \mathrm{~m}^{3}$ ) et un étang perméable (ca. $7000 \mathrm{~m}^{3}$ ), avec des écrevisses depuis moins de deux ans, à l'exception de celles présentes dans la sablière depuis 6 ans. Des tests 
de toxicité préliminaires ont été conduits dans des seaux avec le substrat pour indiquer les doses de terrain. Dans la sablière et les 3 étangs de retenue, le traitement (octobre 2004 , température de l'eau $13^{\circ} \mathrm{C}$ ) a compris la désoxygénation avec du sulfate de sodium pour stimuler l'émergence, et ensuite l'application du pyrèthre naturel (Pyblast). Les berges exposées furent vaporisées à l'avance avec Pyblast pour empêcher la fuite des écrevisses. La mortalité des écrevisses fut élevée, mais un survivant a été vu 5 jours plus tard. Le Pyblast avait été pompé à partir d'un réservoir contenant encore des résidus de sulfate de sodium, ce qui a probablement réduit la concentration de Pyblast en dessous de $0,1 \mathrm{mg}^{-\mathrm{l}^{-1}}$. Un nouveau traitement a été conduit fin Octobre avec $0,15 \mathrm{mg}^{-1} \mathrm{I}^{-1}$ de concentration en Pyblast et 0 en $\mathrm{Na}_{2} \mathrm{SO}_{3}$ (température de l'eau $9{ }^{\circ} \mathrm{C}$ ). La mortalité fut confirmée par l'utilisation d'écrevisses en cage. Aux trois étangs, l'écoulement a été arrêté avant le traitement, les poissons ont été retirés, la végétation des berges a été traitée avec du Pyblast et le reste a été appliqué par bateaux équipés des vaporisateurs, pour tuer les écrevisses. Un suivi biologique a été fait en utilisant des sacs de crevettes d'eau douce (Gammarus) placés dans le cours d'eau adjacent. Le traitement du dernier étang (Décembre, concentration cible $0,2 \mathrm{mg}^{-1} \mathrm{I}^{-1}$, température $4^{\circ} \mathrm{C}$ ) a nécessité le pompage en continu des eaux pendant une période de récupération de deux semaines pour éviter la contamination de la rivière en aval. Une mortalité de $100 \%$ a été obtenue après 5 jours pour les écrevisses en cage. Un contrôle pendant une période de 2 à 5 ans est nécessaire.

Mots-clés : Pacifastacus leniusculus, éradication, biocide, étang, pyrèthre naturel.

\section{INTRODUCTION}

There are no indigenous crayfish in Scotland and the stocking of crayfish into waterbodies in Scotland is illegal. There are concerns about the potential impact of introduced crayfish on indigenous salmonid fisheries (GRIFFITHS et al., 2004) and on aquatic invertebrates in Scotland (CRAWFORD et al., in press). Despite this, there have been several introductions since the late 1990s (P. COLLEN, Fisheries Research Services, pers. comm.).

In 2003, signal crayfish Pacifastacus leniusculus were discovered in the North Esk catchment in Aberdeenshire, Scotland (Figure 1) in a gravel pit and in two nearby ponds. Scottish Natural Heritage (SNH), the agency that advises government on nature conservation in Scotland, consulted with various agencies, the affected landowners and crayfish specialists and decided to try to eradicate the crayfish. It had to be attempted quickly, as with delay the signal crayfish would be increasingly likely to escape from the ponds, become established in the river system and spread beyond any means of control. From the decision to act in August 2004 to start of the treatment was 8 weeks. This approach is consistent with IUCN guidelines (2000), which state that "the best opportunities for eradicating or containing an alien invasive species are in the early stages of invasion, when populations are small and localised". IUCN advice is that "where it is achievable, eradication is the best management option for dealing with alien invasive species where prevention has failed. It is much more cost effective financially than ongoing control, and better for the environment".

In England and Wales there has been a dramatic spread of signal crayfish since the species was first introduced in the late 1970s. This spread has been at the expense of the indigenous white-clawed crayfish Austropotamobius pallipes, as described by SIBLEY (2003). Despite the introduction of legislation to prevent further introductions of signal crayfish, the number and extent of populations grew rapidly and continues to do so (HOLDICH et al., 2004). Efforts were made to find a method with low environmental impact 

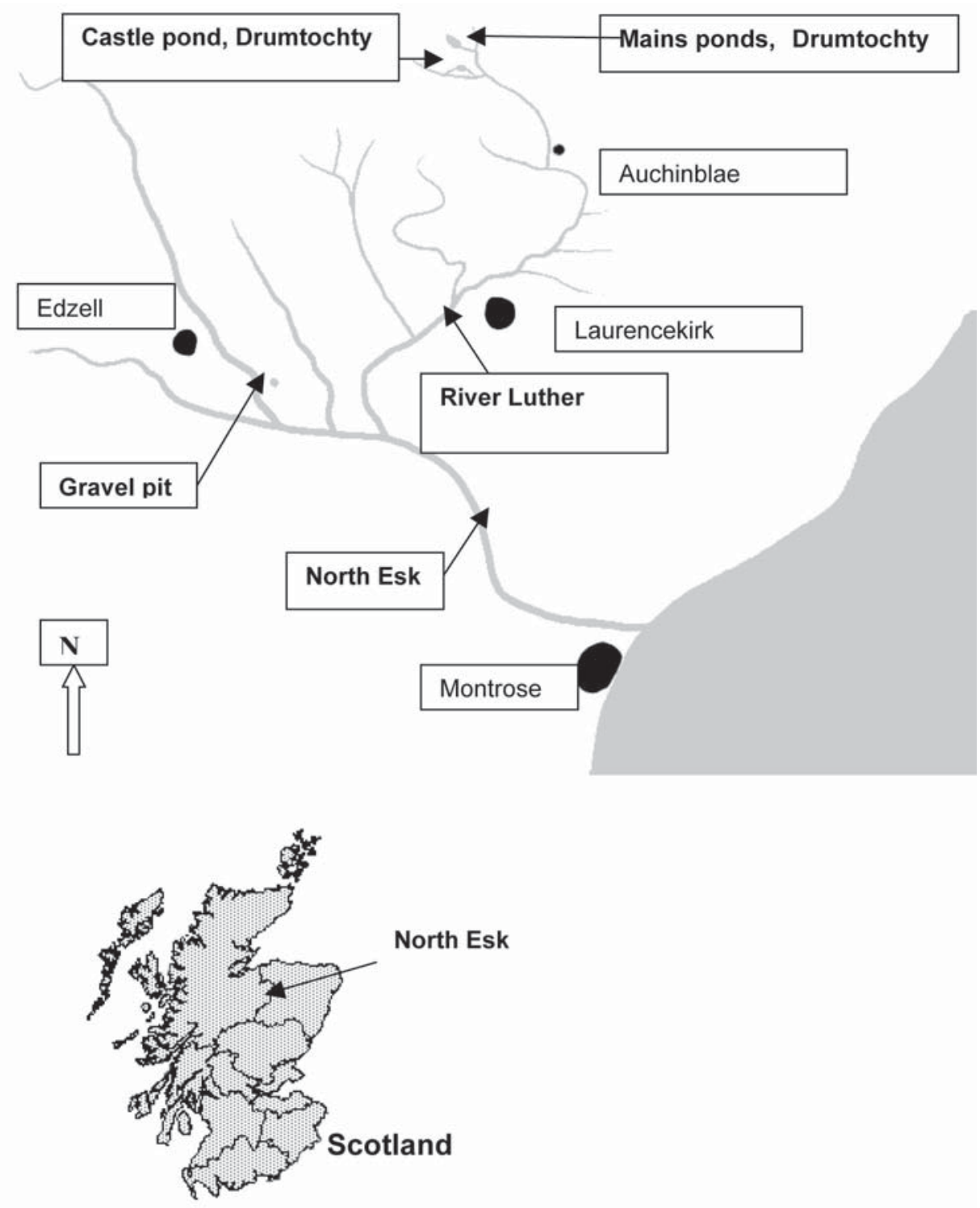

Figure 1

Location of North Esk catchment.

Figure 1

Localisation du bassin de North Esk.

to eradicate unwanted populations of crayfish, but no viable methods were found during a period of more than 25 years. Manual removal, trapping and electrofishing had already been tried unsuccessfully in the River Clyde in Scotland during 2001 to 2003 (C. BEAN, $\mathrm{SNH}$, pers.comm.) and in other projects (PEAY and HILEY, 2001). Methods used did not eradicate signal crayfish, nor limit the rate of invasion. Throughout the period when these methods were under trial, signal crayfish continued to spread in existing colonised catchments and into new ones, where they arrived via canals, by accidental stocking with fish from fish farms and by illegal introduction. Biocides were therefore considered as an alternative option. 
Biocides have been used against crayfish in a few studies, which are reviewed in HOLDICH et al. (1999). There are no known biocides that are selective to crayfish, or even to crustaceans, so those with potential for use against crayfish are also toxic to other aquatic invertebrates and fish.

The botanical insecticide rotenone, derived from various species of the Leguminosae is also used as a piscicide. However, it was reported to have little effect on benthic invertebrates in Scotland (MORRISON and STRUTHERS, 1975, cited in HOLDICH et al., 1999). In laboratory tests, BILLS and MARKING (1988) found they could kill rusty crayfish Orconectes rusticus with rotenone in three days at $10 \mathrm{mg} \mathrm{l}^{-1}$, compared to $0.02 \mathrm{mg} \mathrm{l}^{-1}$ to kill fish. EVERSOLE and SELLER (1997) found that of 35 chemical groups reviewed, synthetic pyrethroids were the most toxic to crayfish, with a median 96-h $L_{50}$ value of $2.5 \mu \mathrm{g} \mathrm{l}^{-1}$, compared to $350 \mathrm{\mu g} \mathrm{l}^{-1}$ and $352 \mathrm{\mu g} \mathrm{l}^{-1}$ for organochlorine and for organophosphates respectively.

There has been little authorised use of biocides against crayfish in Europe. CABRAL et al. (1997) mentioned the illegal use of parathion to prevent crayfish activity in rice fields, but the effectiveness of such treatments is not reported. In one of the few published examples, LAURENT (1995) treated three ponds with the organophosphate insecticide fenthion and achieved $100 \%$ mortality of caged crayfish, but fenthion proved to be persistently toxic in the ponds for many weeks. Statutory authorities may be concerned about the impact of biocides on non-target areas and about the persistence of some products that are authorised for use in agriculture, but not in water (HOLDICH et al., 1999). FRUTIGER et al. (1999) noted that a decision to use a biocide against an unwanted population of non-indigenous crayfish in Switzerland was overturned in a court ruling.

In the search for a biocide with low environmental impact, CABRAL et al. (1997) carried out a detailed study of a surfactant (GENAPOL OX-080), which is biodegradable. Doses were found that would kill red swamp crayfish Procambarus clarkii, but comparison with tests on a fish, a snail and a cladoceran showed that LC $_{50}$ values for the non-target species were 12 to $>80$ times lower than those for the crayfish and even higher doses would have to be used to obtain $\mathrm{LC}_{100}$ of crayfish in field conditions.

Synthetic pyrethroids have been tested on crayfish in laboratories (e.g. EVERSOLE and SELLER, 1997; QUAGLIO et al., 2002). When field tests were planned in England, however, (HILEY and PEAY, 2003) the Environment Agency, the regulatory authority, decided that tests would not be permitted with synthetic pyrethroids, but only with the more readily degradable natural pyrethrum.

In 2000, HILEY (2003) undertook some preliminary laboratory tests on the use of non-persistent biocides on signal crayfish. These initial tests were followed by some field tests, in outside tanks, with substrate and water from a farm reservoir (HILEY and PEAY, 2003 and in press). The tests included chemical deoxygenation with sodium sulphite, high $\mathrm{pH}$, ammonia from nitrogenous fertiliser at high $\mathrm{pH}$, chlorine from sodium hypochlorite and natural pyrethrum. Of these, pyrethrum was considered to be the most suitable for field trials on wild populations of signal crayfish.

Natural pyrethrum is the oldest known botanical insecticide and is produced primarily from the flowers of Chrysanthemum cinerariaefolium and C. cineum, as extracts composed of several natural pyrethrins. It is widely used as an organic insecticide on crops, where it can be applied up to harvest. It is used in food handling premises, for control of insects for public hygiene or avoidance of nuisance and also as a treatment for headlice. It was first used against crustaceans in 1947 to clear infestations of water hoglouse Asellus aquaticus from public water mains (HART, 1958) and is still used in this way, usually at doses of $10 \mathrm{\mu g} \mathrm{l}^{-1}$ (EVINS, 2004). 
The advantages of natural pyrethrum are its low toxicity to mammals and birds (HUDSON et al., 1984; SAXENA and BAKRA, 1978), its rapid breakdown in sunlight, the absence of toxic residues and its harmlessness to plants. It is, however, toxic to other aquatic crustaceans, insects and fish (SANDERS, 1969; JOHNSON and FINLEY, 1980; MAYER and ELLERSIECK, 1986; BURRIDGE and HAYA, 1997). It is also more expensive than more stable synthetic pyrethroid insecticides.

The formulation tested in simulated field conditions by HILEY and PEAY (2003) was Pyblast (Agropharm Ltd), which consists of 3.0\% w/w pyrethrins; plus piperonyl butoxide as a synergist to rapidly immobilise invertebrates, and alcohol ethoxylate.

Pyblast was chosen as the biocide for the attempted eradication of the signal crayfish in the North Esk catchment because, being biodegradable, it was considered to have lower environmental impact than more stable and persistent commercially available insecticides and, specifically, because it was the only insecticide that had been fieldtested on crayfish in the UK.

The decision to use a biocide in these Scottish trials was done with the understanding that any treatment that was sufficiently effective on crayfish would also be lethal to a range of non-target organisms. Hence, when used in field conditions, the biocide would also kill other components of the aquatic fauna. The treated waterbody would have to recover by a process of natural colonisation. The premise was that it was better to have a short-term, fully recoverable impact on a waterbody in a controlled, localised area than to allow signal crayfish to spread throughout the river system, with the associated long-term impacts.

The approach used in the trial treatment was to prevent or minimise the inflow or outflow of water; remove fish where necessary; spray the terrestrial margins with Pyblast to prevent any escape over land; then treat the whole waterbody with Pyblast, and contain the treated water throughout the recovery period to prevent any adverse effects in nontarget areas.

In the first instance, a pre-treatment of deoxygenation with sodium sulphite was used, with the aim of stimulating crayfish to emerge from refuges prior to dosing with Pyblast, but this was omitted later when it was found to interfere with the action of Pyblast.

Authorisations were required from several statutory agencies, the UK Health and Safety Executive Biocide and Pesticides Unit and Scottish Environmental Protection Agency (SEPA) for approval to use the biocide and the Scottish Executive for a licence to hold signal crayfish.

The primary purpose of the work was to eradicate signal crayfish from the North Esk catchment, although scientific study was included. This paper is, therefore, not a laboratory-based ecotoxicology study, but instead is more descriptive and deals with the practical problems of moving up in scale from tests to full-scale treatments in waterbodies of thousands of cubic metres and with uncontrolled environmental conditions.

\section{SITES}

The five waterbodies that were treated are described in Table I. They consisted of a wholly enclosed gravel pit, a chain of three ponds (Mains ponds) and a separate off-line pond (Castle pond) near a river, the River Luther, ranging in size from 0.1 to 1.0 ha. Signal crayfish had reputedly been stocked in the gravel pit in 1998 and into the other ponds in 2003. Trapping surveys confirmed there were populations of crayfish in two of the ponds (lower Mains and Castle) and an abundant population in the gravel pit. No crayfish were found in a manual search of the River Luther in early October 2004, but two juveniles were found in a $10 \mathrm{~m}$ length of ditch immediately downstream of Castle Pond. The rest of the 


\section{Table I}

Waterbodies treated in North Esk catchment, with results of pre-treatment trapping.

Tableau I

Cours d'eau traités dans le bassin North Esk.

\begin{tabular}{|c|c|c|c|}
\hline Location & $\begin{array}{c}\text { Size } \\
\text { (approx.) }^{1}\end{array}$ & Description & $\begin{array}{l}\text { Results of } \\
\text { pre-treatment } \\
\text { trapping }\end{array}$ \\
\hline $\begin{array}{l}\text { Small pond } \\
\text { (Mains ponds } \\
\text { Drumtochty) }\end{array}$ & $\begin{array}{l}\text { Area: } 80 \mathrm{~m}^{2} \\
\text { Volume: } \\
\text { c. } 80 \mathrm{~m}^{3}\end{array}$ & $\begin{array}{l}\text { One of a chain of dammed ponds } \\
\text { in ungrazed grassland with rushes } \\
\text { and trees. It has steep, sandy clay } \\
\text { banks. There is an inflow from } \\
\text { field drainage and an outlet to } \\
\text { Middle pond. Stocked with brown } \\
\text { trout (Salmo trutta). No known } \\
\text { introduction of crayfish. }\end{array}$ & $\begin{array}{l}\text { September } 2004, \\
5 \text { traps, } 0 \text { crayfish }\end{array}$ \\
\hline $\begin{array}{l}\text { Middle pond } \\
\text { (Mains ponds } \\
\text { Drumtochty) }\end{array}$ & $\begin{array}{l}\text { Area: } 1,500 \mathrm{~m}^{2} \\
\text { Volume: } \\
\text { c. } 1,750 \mathrm{~m}^{3}\end{array}$ & $\begin{array}{l}\text { Pond as above, outfalls through } \\
\text { dam to Lower pond. No known } \\
\text { introduction of crayfish. }\end{array}$ & $\begin{array}{l}\text { September } 2004, \\
15 \text { traps, } 0 \text { crayfish }\end{array}$ \\
\hline $\begin{array}{l}\text { Lower pond } \\
\text { (Mains ponds } \\
\text { Drumtochty) }\end{array}$ & $\begin{array}{l}\text { Area } 3,000 \mathrm{~m}^{2} \\
\text { Volume: } \\
\text { c. } 3,000 \mathrm{~m}^{3}\end{array}$ & $\begin{array}{l}\text { Pond has several vegetated } \\
\text { islands and numerous trees } \\
\text { standing in water. It has sparse } \\
\text { aquatic vegetation of Callitriche } \\
\text { sp., Myriophyllum alternifolium and } \\
\text { Potamogeton natans. pH } 6.94 \text {, } \\
\text { alkalinity } 123 \mu \text { eq I-1 } \text {, conductivity } \\
97 \mu \mathrm{cm}^{-1} . \text { Has piped outfall } \\
\text { through earth dam to a small } \\
\text { stream. Stocked with trout. } \\
\text { Reputedly stocked with c. } 50 \\
\text { crayfish in spring } 2003 \text {. }\end{array}$ & $\begin{array}{l}\text { July } 2004, \\
10 \text { traps, } 2 \text { crayfish } \\
\text { (CPUE 0.2) Found } \\
3 \text { in unauthorised } \\
\text { trap left on site. }\end{array}$ \\
\hline $\begin{array}{l}\text { Castle pond } \\
\text { (Drumtochty) }\end{array}$ & $\begin{array}{l}\text { Area: } 5,450 \mathrm{~m}^{2} \\
\text { Volume: } \\
6,100 \mathrm{~m}^{3}\end{array}$ & $\begin{array}{l}\text { Inlet ditch from river via step } \\
\text { cascade. Outfall pipes through } \\
\text { dam. Substrate clay, locally with } \\
\text { gravel/cobble; silty especially } \\
\text { in shallows. Banks vegetated } \\
\text { with rushes. pH } 7.48 \text {, alkalinity } \\
531 \mu e q \mathrm{I}^{-1} \text {, conductivity } \\
116 \mu \mathrm{cm}^{-1} \text {. Stocked with brown } \\
\text { trout. Reputedly stocked with } \\
\text { c. } 50 \text { crayfish in spring } 2003 \text {. }\end{array}$ & $\begin{array}{l}\text { July } 2004 ; \\
20 \text { traps, } \\
16 \text { crayfish } \\
\text { (CPUE } 0.8) \text {. } \\
1 \text { crayfish active by } \\
\text { day } 06 / 08 / 04 .\end{array}$ \\
\hline $\begin{array}{l}\text { Gravel pit } \\
\text { (Edzell) }\end{array}$ & $\begin{array}{l}\text { Area: } 6300 \mathrm{~m}^{2} \\
\text { Volume: } \\
\text { c. } 9,000 \mathrm{~m}^{3}\end{array}$ & $\begin{array}{l}\text { Old gravel pit with no inlet or } \\
\text { outlet. Moderately steep, bare } \\
\text { margins. Substrate soft gravel, } \\
\text { some cobble and probably } \\
\text { clay at depth. One area with } \\
\text { Typha latifolia. Submerged } \\
\text { beds of Egeria densa. pH } 7.0 \text {, } \\
\text { alkalinity } 652 \mu \text { eq I-1, conductivity } \\
114 \mu \mathrm{cm}^{-1} \text {. Reputedly stocked } \\
\text { with crayfish in } 1998 \text {. }\end{array}$ & $\begin{array}{l}\text { 29/08/03, } 10 \text { traps, } \\
150 \text { crayfish. } \\
\text { Many active by } \\
\text { day 06/08/04. } \\
\text { 03/10/04: } 40 \text { traps } \\
\text { (CPUE 3.0). }\end{array}$ \\
\hline
\end{tabular}


ditch to the river was badly polluted with fuel oil, with a very sparse benthic fauna and was considered to be unsuitable for crayfish. The small stream next to the Mains ponds was kick-sampled, but conditions were not favourable for manual survey for crayfish and it was too shallow and fast for trapping, so it could not be confirmed that the crayfish were confined to the pond.

\section{METHODS}

\section{Preliminary tests}

Preliminary toxicity tests were carried out off-site to indicate the recovery time required after treatment. Tanks were set up outside with 20 I rainwater at c. $13^{\circ} \mathrm{C}$, with or without a bed of sandy clay sub-soil. Pyblast was added to a dilution of $0.1 \mathrm{mg} \mathrm{l}^{-1}$ natural pyrethrins, with or without prior deoxygenation with sodium sulphite $(20 \mathrm{ml}$ saturated solution). In one treatment the tank was kept in the dark without aeration to simulate conditions in deep water. Samples of 20 water hog-louse Asellus aquaticus were put into the tanks, in numbered mesh bags with pieces of partly decomposed leaf as food, starting 24 hours after the treatment. Bags were inspected at intervals and fresh ones added until Asellus survived in all treatments. Aeration of tanks was started 24 hours after treatment and continued for 6 days, as Asellus would not survive in anoxic conditions.

Signal crayfish for field tests were obtained from wild stocks at the gravel pit and elsewhere. Crayfish were stored in cool, wet conditions, in crates with plastic flowerpots as refuges for a few days. At the sites they were kept in submerged cages in untreated local water until required. Only healthy, active animals were used in the tests.

Preliminary toxicity tests with crayfish were set up on site using local substrates and water, with deoxygenation, then Pyblast at 0, 0.01, 0.05, 0.1 and $0.2 \mathrm{mg} \mathrm{l}^{-1}$ natural pyrethrins, plus controls of substrate and water alone (as HILEY and PEAY, 2003). The condition of crayfish was assessed, as in Table II, as an indication of progress to mortality. Crayfish were also tested on dry substrate sprayed with Pyblast. Air temperature was in the range $10-14^{\circ} \mathrm{C}$ and conditions were dry for a week.

\section{Table II}

Qualitative assessment of condition of crayfish.

\section{Tableau II}

\section{Evaluation qualitative de la condition des écrevisses.}

\begin{tabular}{|l|l|l|}
\hline \multicolumn{1}{|c|}{ Ref. } & \multicolumn{1}{c|}{ Condition } & Comments \\
\hline SR & self-righting & normal condition, no apparent effect \\
\hline SSR & slow self-righting & $\begin{array}{l}\text { movement slow and often stiff, may take 1 min or } \\
\text { more to turn over if placed on back, even in water }\end{array}$ \\
\hline NSR & not self-righting & $\begin{array}{l}\text { significantly affected, lying on back, but still making } \\
\text { voluntary movements of limbs, in water or air }\end{array}$ \\
\hline T & torpid & $\begin{array}{l}\text { no voluntary movement, lying on back, will show } \\
\text { slight movement of limbs when touched, but in } \\
\text { more advanced stages moribund animals may } \\
\text { show minimal response or just movement of } \\
\text { mouthparts }\end{array}$ \\
\hline D & dead & no response to touching, no eye-stalk response \\
\hline
\end{tabular}




\section{Eradication programme}

Fish were removed by netting prior to treatment of the ponds. The gravel pit was treated on 5th October 2004. A $1 \mathrm{~m}$ wide band of the bare margin was sprayed with Pyblast, at a rate of 1 I concentrate in 9 I water applied to $200 \mathrm{~m}^{2}$, to prevent any crayfish escaping. Sodium sulphite was sprayed over the surface at a dose rate of $0.16 \mathrm{~kg} \mathrm{~m}^{-3}$, but was first dissolved in a large tank. The Pyblast concentrate was then mixed with water in the same tank, within 2 hours of completion of the application of sodium sulphite, and was sprayed over the gravel pit to achieve a target dosage of $0.1 \mathrm{mg} \mathrm{l}^{-1}$ natural pyrethrins.

A dissolved oxygen meter was used to monitor deoxygenation. Night-viewing of the exposed margins and shallows was carried out by torchlight on nights 1,2,3 and 5 after treatment to check for live, dying and dead crayfish. Crayfish were collected during the day after treatment from 9 quadrats $\left(1 \mathrm{~m}^{2}\right)$ in the shallow margins of the gravel pit and were sexed and measured. Water samples were collected from near the surface and in deep water. Healthy crayfish were placed in buckets with the water samples. In the controls healthy crayfish were put in untreated water from the site, which had been stored in tanks prior to the biocide treatment. The condition of crayfish was observed over 48 hours. Dead and dying crayfish were removed from the margins to minimise the small risk of herons or other predators taking any affected, but still viable crayfish and losing the prey at another site. Although various piscivorous birds were active in the area, natural pyrethrum does not bioaccumulate and has very low toxicity to birds, so consumption was not considered to be a risk.

The flow through the three Mains ponds was diverted to the adjacent stream and seepage from the lower pond was collected and pumped back during the period of treatment and recovery. Samples of aquatic invertebrates from the adjacent stream were put into mesh bags in the stream upstream and downstream of the lower pond. The Mains ponds were treated by dry application of sodium sulphite, followed immediately by Pyblast applied by boat-mounted sprayer to a target dosage of $0.1 \mathrm{mg} \mathrm{l}^{-1}$ natural pyrethrins. The margins, the trunks of trees standing in water and small, marshy islands were all treated with Pyblast. Water samples were taken one day after treatment for toxicity tests with healthy crayfish, as at the gravel pit.

Five days after treatment, a single live crayfish was seen walking by day at the gravel pit, so $100 \%$ mortality had not been achieved. Further outdoor toxicity tests were carried out off-site in tanks with rainwater and sandy clay substrate. One series involved a variable concentration of sodium sulphite as a pre-treatment; at $1 \mathrm{ml} \mathrm{l}^{-1}$ (the standard rate), 0.5, 2 or $5 \mathrm{ml} \mathrm{l}^{-1}$, followed by natural pyrethrins at $0.1 \mathrm{mg} \mathrm{l}^{-1}$. In the other series, deoxygenation was omitted and the natural pyrethrin dose was varied, this time to $0.05 \mathrm{mg} \mathrm{l}^{-1}, 0.1 \mathrm{mg} \mathrm{l}^{-1}$, $0.2 \mathrm{mg} \mathrm{l}^{-1}$ and $0.5 \mathrm{mg} \mathrm{l}^{-1}$. Controls were included as usual. Water temperature was in the range $7-9^{\circ} \mathrm{C}$. Tests were observed for four days. These off-site toxicity tests showed that sodium sulphite reduced the toxicity of Pyblast (see Results).

The protocol was subsequently modified to omit deoxygenation and the gravel pit was re-treated with a higher target dose of $0.15 \mathrm{mg} \mathrm{l}^{-1}$ Pyblast on $29^{\text {th }}$ October, when the water temperature was $8.5^{\circ} \mathrm{C}$. Before the treatment, batches of 10 crayfish were put into each of twenty weighted cages and deployed in the gravel pit. The size distribution of the test animals was $14 \%$ in the size class $20-29 \mathrm{~mm}$ CL (carapace length), 33\% 30-39 mm and $53 \% 40 \mathrm{~mm}$ or more. Half the cages were briefly inspected one day after treatment. All the cages were lifted after 2 days in treated water and the condition of each crayfish was assessed. Any animals that were still live were returned in the cages and lifted after 4 days exposure to the treatment. Toxicity tests were carried out with healthy crayfish in water samples taken 1 day after treatment. 
Investigations were required to assess leakage from Castle pond and control it before the pond could be treated. Loss of water via old field-drains was intercepted by excavation of a sump, plus installation of temporary dams in the outfall ditch. The inflow from the river was shut off and water was retained in the pond by continuous pumping throughout the treatment and recovery period. Mesh bags with freshwater shrimps (Gammarus) were installed in the river upstream and downstream of the outfall ditch prior to the treatment and these were monitored several times a day.

Crayfish were set out in 18 cages (10 per cage) in the pond and 2 cages in the intercept channel and sump that collected the leaking water. The margins were sprayed with Pyblast and the pond was treated to obtain a target dosage of $0.2 \mathrm{mg} \mathrm{l}^{-1}$ natural pyrethrins on $12^{\text {th }}$ December. The water temperature was $3.5-4.5^{\circ} \mathrm{C}$. As in the previous treatment, water samples were tested on healthy crayfish 24 hours after treatment. The condition of crayfish in cages was checked after 48 and 72 hours and any crayfish surviving were then moved to untreated aerated water to check for any recovery. A new cage of healthy crayfish was put in the pond three days after the treatment and left there until January.

Toxicity tests were carried out with Asellus to monitor the recovery, in undiluted treated water taken from the surface, in treated water diluted by factors of 10, 100, 1,000 and 10,000 , and with a control of river water alone. Six series of tests were carried out during 14th-23rd December. Pumping continued until 27th December, 15 days after treatment of the pond, after which water was allowed to enter the river via the outfall ditch.

\section{RESULTS}

\section{Results of preliminary tests}

The preliminary recovery tests with Asellus (at $13^{\circ} \mathrm{C}$ ) showed that for the first two days Asellus exposed to any treatment died within 24 hours. In the deoxygenation and Pyblast treatment at $0.1 \mathrm{mg} \mathrm{l}^{-1}$ natural pyrethrins with clay, $\mathrm{LC}_{50}, 24$ hours occurred on the third day post-treatment. In this and other tests, any Asellus that survived the first 48 hours of exposure to treated water survived thereafter. Full survival occurred from 5 days with this treatment. The treatment with Pyblast and clay, but no deoxygenation took 7 days to reach $\mathrm{LC}_{50}, 24$ hours, 4 days longer than with the prior deoxygenation. The treatment with deoxygenation and Pyblast kept in the dark without aeration remained toxic for up to 20 days. Pyblast treatment without clay was the most persistently toxic, with $\mathrm{LC}_{50}, 24$ hours at about 17 days, 14 days longer than with deoxygenation and clay substrate present. Full recovery was at 21 days in the treatment with Pyblast alone. Depending on the treatment, it took 2-4 days from the first Asellus surviving 24 hours to all individuals surviving for 48 hours or more. Both prior deoxygenation and clay reduced the recovery time compared to treatment with Pyblast alone in clean conditions.

Preliminary toxicity tests with crayfish and substrate and water from the gravel pit showed doses of $0.1 \mathrm{mg} \mathrm{l}^{-1}$ and $0.2 \mathrm{mg} \mathrm{l}^{-1}$ natural pyrethrins, preceded by deoxygenation, killed the crayfish within 24 hours in tests when the water was at $10^{\circ} \mathrm{C}$. A lower dose of $0.05 \mathrm{mg} \mathrm{l}^{-1}$ killed half the crayfish in 24 hours, whereas $0.01 \mathrm{mg} \mathrm{l}^{-1}$ and deoxygenation alone only killed a quarter of them.

The preliminary tests at Castle pond were extreme, because silty mud was used in each tub, which with the activity of the crayfish, kept the water completely opaque. None of the crayfish (4 crayfish in each of 2 replicates) died within 24 hours in these tests, although most did so in tests with $0.1 \mathrm{mg} \mathrm{l}^{-1}$ and $0.2 \mathrm{mg} \mathrm{l}^{-1}$ in 2 days and the few not dead were moribund. By contrast, with deoxygenation alone, 7 of 8 crayfish survived, even after 39 hours of anoxic conditions (at c. $4^{\circ} \mathrm{C}$ ). 
In preliminary tests at the gravel pit without clay, observations were made of behaviour during treatment (as in HILEY and PEAY, 2003). Crayfish became much more active than controls as dissolved oxygen fell from 10.5 to $2 \mathrm{mg} \mathrm{l}^{-1}$ and it was only at $0 \mathrm{mg} \mathrm{l}^{-}$ 1 that crayfish became torpid, with most seen on their backs at the bottom of the tank. Increased activity was seen in the gravel pit during deoxygenation, as well as in the bucket tests with deoxygenation. Increased activity, including tail-flipping, was also noted during the early stages of the toxicity tests carried out with Pyblast and substrate only.

Crayfish were immediately affected when placed on sprayed gravel, 3 minutes after the application, by which time the gravel was dry. When crayfish were allowed to walk over the gravel 3 to 4 hours after treatment, stiffness and loss of balance were apparent within 2-3 minutes, after which they were removed. All the crayfish exposed to the dry, sprayed substrate were dead within 28 hours.

Toxicity tests carried out with crayfish off-site, after the first treatment, confirmed the treatments with deoxygenation were less toxic to the crayfish, although there was little variation in effect evident with increasing doses of sodium sulphite. At doses of $0.2 \mathrm{mg} \mathrm{l}^{-1}$ or $0.5 \mathrm{mg} \mathrm{l}^{-1}$ natural pyrethrins with clay, but no deoxygenation, all the crayfish died in 24 to 48 hours. At $0.1 \mathrm{mg} \mathrm{l}^{-1}$ one crayfish was still alive in a torpid condition after 48 hours. It improved slightly when put in clean water, but was still not self-righting after 36 hours recovery, i.e. 4 days after the treatment. By contrast, with deoxygenation alone, torpid crayfish appeared to recover fully within an hour of being placed in well-aerated water.

\section{Results of eradication programme}

During the first treatment, the clarity in the gravel pit increased slightly as crayfish activity ceased. However, an increase in the number of dead crayfish in the shallows, from 87 on the first night to 552 on the third night, reflects increased mortality rather than better visibility. The number of live crayfish seen each night decreased from 32 a few hours after treatment, to 2 on the second night, 1 on the third night and none thereafter. This would have been encouraging, except for the appearance of an active crayfish on day 5 .

Density ranged from 1 to 17 crayfish $\mathrm{m}^{-2}$, with an average of 7 crayfish $\mathrm{m}^{-2}$, and $89 \%$ mortality in the quadrats on the day after treatment. The size distribution is shown in Figure 2. In the quadrats $72 \%$ of the crayfish were juveniles less than $20 \mathrm{~mm} \mathrm{CL}$ (carapace length) and all of those were dead. The other $28 \%$ were $25 \mathrm{~mm} \mathrm{CL}$ or more in size and of those $10 \%$ were still alive about 20 hours after treatment, although they all died during the following 48 hours. In the unvegetated shallow margins there was little or no cover and no in-bank refuges, as the moderately steep gravel slope was relatively soft, with no burrows evident. The few crayfish that were seen alive after 24 hours were all measured or estimated to be more than $20 \mathrm{~mm} \mathrm{CL}$ (carapace length). Although some live but affected crayfish were seen at the water's edge with their heads or tails out of water on the first night, none were found fully out on the exposed gravel margins by day or night.

At the Mains ponds vegetation and detritus made viewing difficult after treatment. Approximately 40 dead crayfish were seen around the partially screened outfall from the lower pond, although no detailed count was made there. After treatment of the Mains ponds, only the water samples taken from the Middle pond killed all the crayfish within 24 hours; the other 4 samples had incomplete mortality and two had crayfish that were still self-righting, an early indication of reduced effectiveness of that treatment.

Water samples taken from the gravel pit 24 hours after the first treatment killed $60 \%$ of the test crayfish within 24 hours and $75 \%$ in about 48 hours. The samples from deep water were more effective than surface ones, probably because of the density of the Pyblast solution, which initially sinks to the bottom as a diffuse milky layer. In samples taken about 40 hours after the treatment of the gravel pit only about half the crayfish added were dead within 48 hours. 


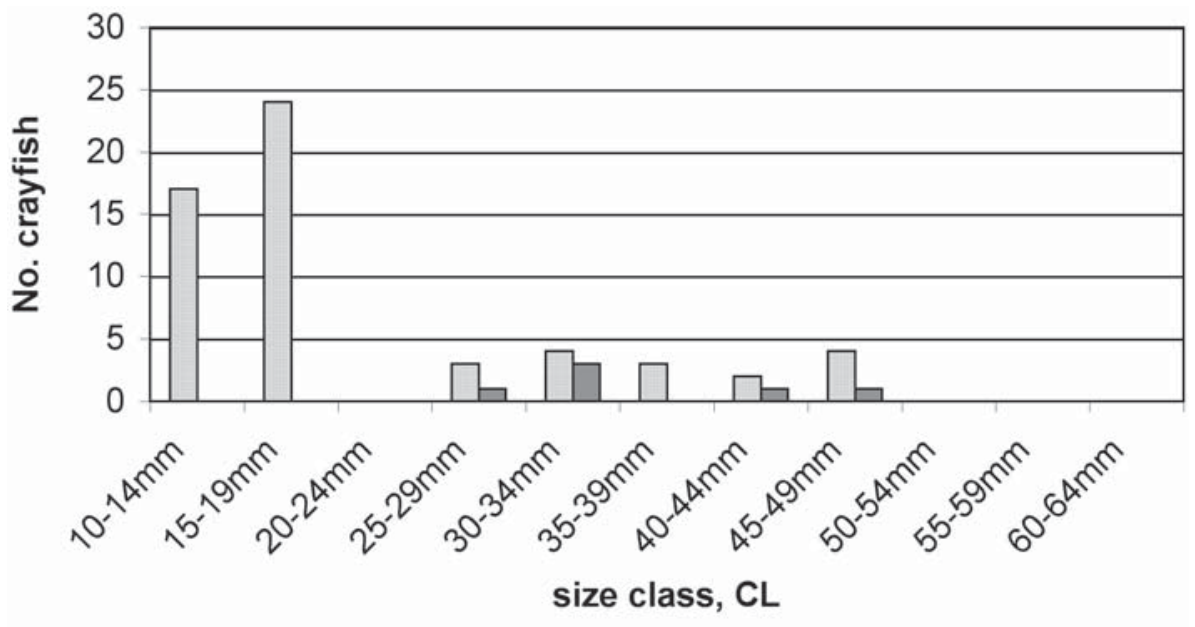

$\square$ Dead in quadrats $\square$ Live in quadrats

\section{Figure 2}

Crayfish recorded on the day after stage 1 treatment of gravel pit (in 9 no. $1 \times 1 \mathrm{~m}$ quadrats).

\section{Figure 2}

Quantité d'écrevisses observées pendant la journée après l'étape 1 de la sablière (dans 9 carrés de $1 \mathrm{~m}^{2}$ ).

On the day after spraying the gravel pit with Pyblast alone only 3 of 10 cages inspected contained crayfish that were still self-righting. After 2 days, only 8 crayfish (4\%) showed any voluntary movement of their limbs, compared to $124(66 \%)$ that were torpid and a further 66 (33\%) from the 20 cages confirmed as dead. Figure 3 shows the condition of caged crayfish after 2 days exposure to treated water. The size distribution reflects the collection of test animals elsewhere by fyke-netting (median $40 \mathrm{~mm} \mathrm{CL}$ ), rather than the actual size distribution in the gravel pit. The proportion of dead crayfish in the size range 20-39 mm CL was $21.5 \%$, compared to $11.5 \%$ of those greater than $40 \mathrm{~mm}$, a significant difference $\left(\mathrm{chi}^{2}=4.645, \mathrm{P}<0.05\right)$. After 5 days all the caged crayfish were dead, except for $7(3.5 \%)$ that were moribund, with only eye-stalk response.

The toxicity tests showed that 1 day after the re-treatment of the gravel pit the water was still toxic enough to severely debilitate all the healthy test animals within 24 hours and kill them all within 48 hours. The treatment killed at least some wild-living survivors of the first treatment, as two crayfish were found recently dead in shallow water 2 days after treatment (female $29 \mathrm{~mm} \mathrm{CL}$ and male $28 \mathrm{~mm} \mathrm{CL}$ ).

At Castle pond, despite the slightly higher dose and colder temperature (water at $4^{\circ} \mathrm{C}$, rather than $9^{\circ} \mathrm{C}$ ), the proportion of crayfish dead in cages after two days was broadly similar to that found at the same stage during the retreatment of the gravel pit; $0.5 \%$ (1 crayfish) with some voluntary limb movement, but not self-righting, 63.7\% torpid and $35.7 \%$ dead. The crayfish in the two cages in the intercept ditch and sump had less than 18 hours exposure in total, as they were lifted during essential operations in the posttreatment period. There was no difference evident in the condition of these compared to the other 18 cages. Although the surviving crayfish from the cages were put into aerated water three days after the start of the treatment, they were all dead after 2 days in the recovery tanks, i.e. within 5 days of the treatment of the pond. 


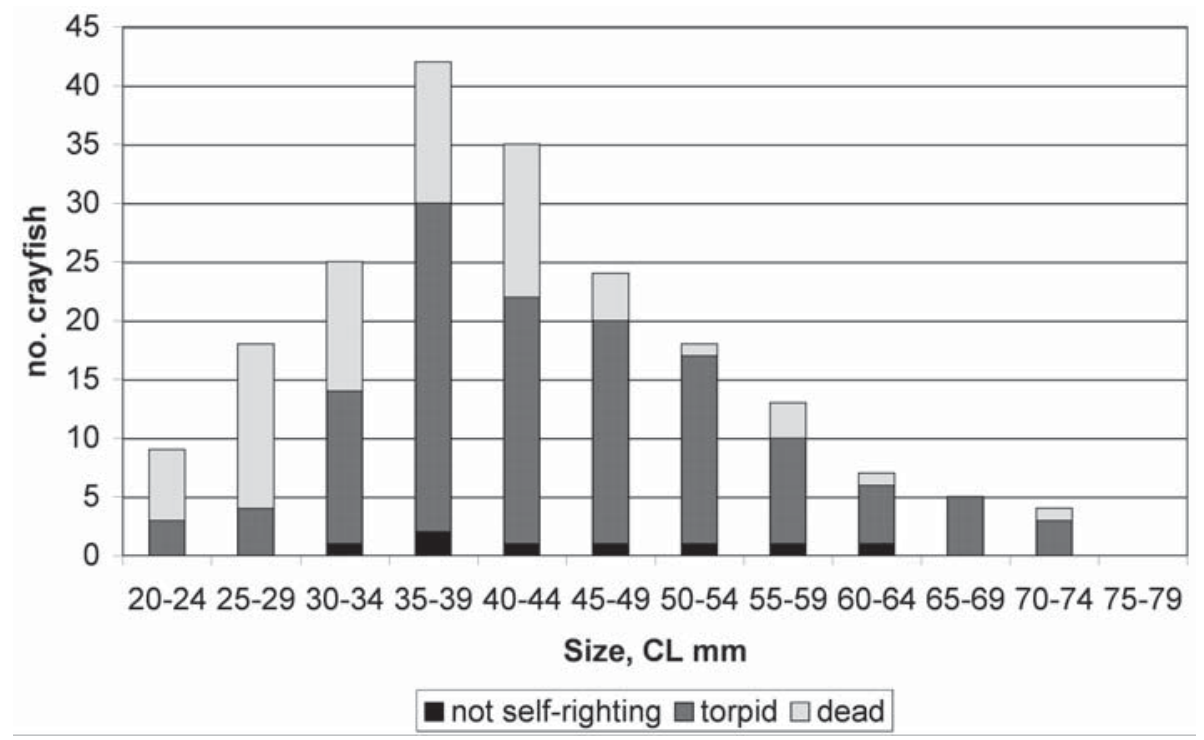

Figure 3

Re-treatment of gravel pit, condition of caged crayfish 2 days after treatment, by size.

Figure 3

Condition et taille des écrevisses en cage 2 jours après traitement pour la sablière après retraitement.

Toxicity tests carried out with water samples collected 24 hours after the treatment of the Castle pond showed half the test crayfish were dead and half torpid and in poor condition 48 hours after exposure to treated water. There was a small continuous inflow of clean water, which would have locally diluted the Pyblast. Crayfish placed in a water sample taken in the pond $2 \mathrm{~m}$ or so from the inflow showed slightly better condition than those in samples from other parts of the pond.

Treatment with Pyblast brought at least some of the wild-living crayfish out of their refuges at Castle pond. Eleven were found lying in the margins, despite poor visibility caused by the pumping operation. Not all of these were dead on the day after Pyblast treatment, but they all died subsequently. The crayfish that were put in a cage three days after the treatment and left for four weeks all died.

Three days after treatment of Castle pond the water was toxic enough to kill Asellus at $100 x$ dilution, although some Asellus were able to survive in water at this dilution 4 days after treatment. 11 days after treatment Asellus were surviving in 10x dilution and effects were starting to ameliorate in undiluted pond water. The bags of Gammarus in the river survived throughout the period of treatment and pumping in December. However, when the bags were lifted on 14th January, there were live shrimps upstream of the outfall ditch, but they were all dead downstream, indicating there had been an impact on aquatic macroinvertebrates when the outfall ditch was opened 15 days after treatment. In spring 2005 there was an increase in the cover of filamentous algae $3.5 \mathrm{~km}$ downstream and the insect and crustacean fauna had been reduced (as recorded in biological monitoring by SEPA). In contrast, the samples of macroinvertebrates in the bags upstream and downstream of the Mains ponds were all alive two weeks after water had been released.

A small number of 1+ roach Rutilus rutilus were killed within 30 minutes of Pyblast application at the gravel pit and some stocked brown trout Salmo trutta were affected 
at the Mains ponds and Castle pond. There was no mortality of fish outside the treated sites.

Aquatic invertebrates had started to recolonise the gravel pit in the 24 days between the first and second treatments and Corixidae were abundant. In the Mains pond, where the treatment was not fully effective, live water beetles were seen within a week of the treatment. Brown trout were stocked into Castle pond in April 2005 and there were no adverse effects.

A trapping survey was carried out in summer 2005, with a total of 100 trap nights at the gravel pit and 43 trap nights at Castle pond. No crayfish were recorded at either site. In the lower Mains pond, 25 trap nights yielded three male crayfish (45, 55 and $59 \mathrm{~mm} \mathrm{CL}$ ).

\section{DISCUSSION}

The eradication programmes show that treatment with Pyblast alone at a target dosage of $0.15 \mathrm{mg} \mathrm{l}^{-1}$ at $9^{\circ} \mathrm{C}$ and $0.2 \mathrm{mg} \mathrm{l}^{-1}$ at $4^{\circ} \mathrm{C}$ was sufficient to kill the caged crayfish in the waterbodies treated. Monitoring will be required for several years to see whether eradication has been achieved, but the initial indications from trapping are favourable, with no crayfish caught so far.

The pre-treatment of deoxygenation with sodium sulphite was not successful, as evidenced by the failure of the first treatment at the gravel pit and in the Mains ponds. The Mains ponds have been retreated with Pyblast in September 2005. In the field tests in summer 2003 (HILEY and PEAY, 2003), Pyblast at $0.05 \mathrm{mg} \mathrm{l}^{-1}$ with prior deoxygenation by sodium sulphite killed all the test animals within 24 hours, when the temperature was at least $20^{\circ} \mathrm{C}$. That treatment only killed half the crayfish in 24 hours in the preliminary tests at $13^{\circ} \mathrm{C}$, although the target dose of $0.1 \mathrm{mg} \mathrm{l}^{-1}$ killed the crayfish within 24 hours. When scaled up in the gravel pit, however, the dosage was not sufficient to kill all the crayfish.

In addition to the issue of field scale, this confirms temperature as a significant factor, one which cannot be controlled in field-tests and treatments, although it can be predicted from climatic records. MAYER and ELLERSIECK (1986) reported that an increase in temperature of $10^{\circ} \mathrm{C}$ increased the toxicity of most toxicants to fish by a factor of 3.1, although EVERSOLE and SELLER (1997) noted that this does not necessarily apply in the same way to crayfish.

Based on information from the manufacturers, it was expected that the presence of clay and organic matter would affect the efficacy of the Pyblast. This was supported by the toxicity tests conducted at the gravel pit, where $0.1 \mathrm{mg} \mathrm{l}^{-1}$ natural pyrethrins with deoxygenation killed the crayfish within 24 hours, whereas the same treatment with a lot of silty clay from Castle pond resulted in no mortality until 36 hours elapsed. Tests with Asellus also showed more rapid loss of toxicity of Pyblast with substrate present than with water alone.

Other authors have also noted that substrate can reduce the effectiveness of pesticides. KOZAK and POLICAR (2003) applied chlorinated lime to a pond at a rate calculated to deliver at least $15 \mathrm{mg} \mathrm{l}^{-1}$, a dosage that was expected to be lethal to crayfish. They only recorded a maximum of $0.75 \mathrm{mg} \mathrm{l}^{-1}$ in situ, which was sufficient to kill caged fish, but not crayfish. The authors attributed this to the binding of active chlorine to the sediment. Similarly, HILEY and PEAY (2003) found initial concentrations of $15 \mathrm{mg} \mathrm{l}^{-}$

1 chlorine did not achieve $100 \%$ mortality with clay substrate present. Initial doses of $30 \mathrm{mg} \mathrm{l}^{-1}$ or more were required to achieve complete mortality within 24 hours in the tests and the chlorine degraded very rapidly after application. The authors concluded that the treatment would not be reliable if used in ponds. 
Differences between laboratory tests and treatments in the field have been reported in the use of insecticides in rice crops where crayfish are also produced commercially. $\mathrm{CHEAH}$ et al. (1979) cites a 48-hour $\mathrm{LC}_{50}$ of $3.4 \mathrm{\mu g} \mathrm{l}^{-1}$ for the insecticide methyl parathion on Procambarus acutus acutus (ALBAUGH, 1972), whereas with a field application equivalent to $100 \mathrm{\mu g} \mathrm{I}^{-1}$ (HENDRICK et al., 1966) there was no effect.

In laboratory conditions, LAURENT (1995) recorded 100\% mortality of Orconectes limosus in 24 hours with a concentration of $0.1 \mathrm{mg} \mathrm{l}^{-1}$ of the insecticide fenthion. When fenthion was used in three ponds, the time required to achieve complete mortality of caged crayfish was 59, 96 and 87 hours for calculated concentrations of $0.13,0.08$ and $0.06 \mathrm{mg} \mathrm{l}^{-1}$ respectively. This accords with our findings that it sometimes took up to 96 hours to kill all the caged crayfish at dosages that were effective within 24 hours in field toxicity tests.

The observation of more rapid mortality of juvenile crayfish in the first treatment of the gravel pit is consistent with the comparative toxicology compiled by EVERSOLE and SELLER (1997). They found that the geometric means of the $L_{50}$ values from juvenile to adult crayfish were 0.7 to 3.2 respectively.

For full-scale application, the minimum effective concentration may be higher than that determined in field tests. EVERSOLE and SELLER (1997) commented on problems of transferring laboratory-derived acute toxicity values to the field, where conditions produce more unpredictable effects. They noted that "acute $\mathrm{LC}_{50}$ values continue to be a mainstay in toxicity testing". For those attempting an eradication of crayfish, or anything else, LC $_{50}$ represents failure and the quoted $\mathrm{LC}_{50}$ is likely to be substantially less than the minimum required in the field. LC $_{100} 24$ hours would be a more useful value from which to start field toxicity tests.

The outdoor toxicity tests with local water and substrates were a valuable intermediate step between laboratory tests in clean conditions and full-scale treatment. Even so, with a range of environmental factors operating, it may be appropriate to set the target dose for an eradication treatment above the minimum dose that achieves $100 \%$ mortality within 24 hours in such outdoor toxicity tests, perhaps by $50 \%$ or more. Factors operate in combination in the field, including the water temperature; the substrate, which varied within each site; the presence of vegetation; topography of habitat; the depth of water, the daylength and light intensity during and after treatment. These influence the exposure of crayfish to the toxicant, its effectiveness and its persistence.

The cages of crayfish helped monitor the treatment, a technique used earlier by LAURENT (1995). Where crayfish were still self-righting, or not self-righting but with active limb movements after 48 hours exposure, there was the potential for recovery, or a risk that wild crayfish within refuges had not been adequately exposed to the toxicant. Where caged crayfish were severely affected in less than 24 hours there was a better chance of hidden crayfish being killed too. In the Castle pond, water that passed through the bed of the pond in leakage was sufficiently toxic to kill crayfish in the muddy sump where leakage was collected. The extra cage put in the pond after three days showed that the water was still sufficiently toxic to kill healthy crayfish. These factors increase the likelihood that crayfish in burrows would receive sufficient exposure, either on the first day, or over a few days.

Pyblast stimulated at least some of the wild crayfish to leave their refuges. Signal crayfish show very little nocturnal activity in winter (BUBB et al., 2002), so the presence of dead and dying crayfish in the margins at Castle pond indicates a response to the biocide, as was observed in the outdoor toxicity tests and at the gravel pit. When the only area of the gravel pit with large stones was searched after the first treatment, some crayfish were found dead in their refuges. Some of these had their tails projecting out 
of the refuge. Signal crayfish tend to sit in their refuges with chelipeds facing forward, suggesting these may have had some time outside the refuges shortly after application of the Pyblast. Perhaps they were using tail-movements to try to circulate fresh water before they succumbed.

Thorough treatment of the margins is especially important where there is submerged and emergent vegetation, or burrows or undercut banks in which crayfish could hide. Crayfish may reach highest density in such areas. Prior removal of vegetation improves penetration of the surface spray, but even so, refuges need to be flooded during treatment, so the water level needs to be maintained at or above normal level.

Monitoring of the eradication treatment using caged fauna in non-target areas and bioassays using dilution series were useful approaches. At Castle pond, however, the water was released before a bioassay confirmed 48 hours survival of Asellus in treated water and this led to impacts on invertebrates in a stretch of watercourse downstream. The release was also made during a period with low flow and hence low dilution in the watercourse. By contrast, at the Mains ponds there was no impact outside the treatment area.

Controlling water in ponds with a throughflow and the various application methods used are discussed in more detail in PEAY and HILEY (2005). The resource requirements and practical difficulties of an eradication treatment should not be under-estimated. Ponds of up to 1 ha in size can be treated within a day using Pyblast alone, but careful advance preparation is needed and sufficient time afterwards for control and monitoring throughout the period when the waterbody is toxic, as well as post-project monitoring. There is a balance to be achieved between dosing heavily to obtain a rapidly lethal dose in all areas of the waterbody and the cost of the product, together with the recovery time before the treated water can be safely released to untreated areas. The recovery time can be a significant factor at sites where water has to be contained by pumping.

This is the first time that there has been any field scale use of a biocide against crayfish in the UK. It is also, as far as we are aware, the first use of natural pyrethrum for this purpose. The trial showed that an eradication treatment can be done safely at field scale, although further monitoring is needed to assess the effectiveness. It is only feasible if the signal crayfish population is limited in extent. Such a treatment is only possible if the landowners and statutory authorities agree that the short-term, localised and recoverable impacts of a biocide are preferable to the extensive and long-term impacts of an invading population of non-indigenous crayfish.

\section{ACKNOWLEDGEMENTS}

The project was undertaken with the cooperation of a number of agencies and individuals. Scottish Natural Heritage provided most of the funding for the project and project management and also provided staff for work on site. Fisheries Research Services provided equipment and staff time for site work and surveys. The Scottish Environment Protection Agency also provided some staff time and Esk District Salmon Fisheries Board contributed to funding. The Environment Agency in England provided wild-caught crayfish for tests. Landowners Jasper Gray and Charlie Anderson and estate worker Dougal Lindsay contributed work on site, equipment and other help in kind. Paul Bryden worked on site and assisted with off-site tests. Anne Lebas kindly carried out the translation into French.

\section{REFERENCES}

ALBAUGH D.W., 1972. Insectide tolerances of two crayfish populations (Procambarus acutus) in South Central Texas. Bulletin of Environmental Contamination and Toxicology, 8, 334-338. 
BILLS T.D., MARKING L., 1988. Control of nuisance populations of crayfish with traps and toxicants. Progressive Fish-Culturist, 50, 103-106.

BUBB D.H., LUCAS M.C., THOM T.J., 2002. Winter movements and activity of signal crayfish Pacifastacus leniusculus in an upland river, determined by radio telemetry. Hydrobiologia, 483, 111-119.

BURRIDGE L.E., HAYA K., 1997. Lethality of pyrethrins to larvae and postlarvae of the American lobster (Homarus americanus). Ecotoxicology and Environmental Safety, 38, 150-154.

CABRAL J.A., ANASTACIO R., CARVALHO R., MARQUES J.C., 1997. A non-harmful chemical method of red swamp crayfish Procambarus clarkii, population control and non target organisms problematics in the lower Modego River valley, Portugal. Freshwater Crayfish, 11, 286-292.

CHEAH M.L. AVAULT J.W., GRAVES J.B., 1979. Some effects of thirteen rice pesticides on crawfish Procambarus clarkii and P. acutus acutus. Freshwater Crayfish, 4, 350361.

CRAWFORD L., YEOMANS W., ADAMS C.E. (in press). The impact of introduced signal crayfish Pacifastacus leniusculus on stream invertebrate communities. Aquatic Conservation.

EVERSOLE A.G., SELLER B.C., 1997. Comparison of relative crayfish toxicity values. Freshwater Crayfish, 11, 274-285.

EVINS C., 2004. Small animals in drinking-water distribution systems. In: AINSWORTH, R., World Health Organisation (Ed.); Safe Pipe Water: Managing Microbial Water Quality in Piped Distribution Systems. IWA Publishing, London, 101-120.

FRUTIGER A., BORNER S., BÜSSER T., EGGEN R., MÜLLER R., MÜLLER S., WASMER H. R., 1999. How to control unwanted populations of Procambarus clarkii in Central Europe? Freshwater Crayfish, 12, 714-726.

GRIFFITHS S.W., COLLEN P., ARMSTRONG J.D., 2004. Competition for shelter among overwintering signal crayfish and juvenile Atlantic salmon. Journal of Fish Biology, $63,436-447$.

HART K.M., 1958. Pyrethrum in the disinfection of public water mains. Pyrethrum Post, $4(3), 8-12$.

HENDRICK R.D., EVERETT T.R., CAFFREY H.R., 1966. Effects of some insecticidees on the survival, reproduction and grouth of the Louisiana red crawfish. Journal of Economic Entomology, 59, 189-192.

HILEY P.D., 2003. Field application of biocides for signal crayfish control. In: HOLDICH D. M. and SIBLEY P.J. (Eds.) Management and Conservation of Crayfish. Proceedings of a conference held on 7th November, 2002. Environment Agency, Bristol. 217 p., 185-199.

HILEY P.D., PEAY S., 2003. Signal crayfish eradication - biocides trial. Project Ref. EIT3401-022. Unpublished report to Environment Agency and English Nature. 29 p.

HILEY P.D., PEAY S. (in press) Signal crayfish eradication - preliminary biocides trial. Freshwater Crayfish, 15.

HOLDICH D.M., GYDEMO R., ROGER, W.D., 1999. A review of possible methods for controlling alien crayfish populations. In: GHERARDI F. and HOLDICH D.M. (Eds) Crayfish in Europe as Alien Species: how to make the best of a bad situation. A.A. Balkema, Rotterdam, 245-270. 
HOLDICH D.M., SIBLEY P.J. and PEAY S., 2004. The white-clawed crayfish - a decade on. British Wildlife, 15, 153-164.

HUDSON R.H., TUCKER R.K., HAEGELE M.A.,1984. Handbook of toxicity of pesticides to wildlife, second edition. US Department of the Interior, Fish and Wildlife Service. Washington, D.C., p. 68.

IUCN, 2000. Guidelines for the prevention of biodiversity loss caused by an alien invasive species. Report by Invasive Species Specialist Group. IUCN, Gland, Switzerland. http://www.iucn.org/themes/ssc/pubs/policy/invasivesEng.htm

JOHNSON W.W., FINLEY M.T., 1980. Handbook of acute toxicity of chemicals to fish and aquatic invertebrates. US Department of the Interior, Fish and Wildlife Service. Washington, D.C., p. 70.

KOZAK. P., POLICAR T., 2003. Practical elimination of signal crayfish Pacifastacus leniusculus (Dana) from a pond. In: HOLDICH D.M. and SIBLEY P.J. (Eds.) Management and Conservation of Crayfish. Proceedings of a conference held on 7th November, 2002. Environment Agency, Bristol. 217 p., 200-208.

LAURENT P.J., 1995. Eradication of unwanted crayfish species of astacological management purposes. Freshwater Crayfish, 8, 121-133.

MAYER F.L., ELLERSIECK M.R., 1986. Manual of acute toxicity: interpretation and database for 410 chemicals and 88 species of freshwater animals. U.S. Department of Interior Fish and Wildlife Resources Publication 160. Washington, D.C. 576 p.

MORRISON B.R.S., STRUTHERS G., 1975. The effects of rotenone on the invertebrate fauna of three Scottish freshwater lochs. Journal of the Institute of Fisheries Management, 6, 81-91.

PEAY S., HILEY P.D., 2001. Eradication of Alien Crayfish. Phase II. Environment Agency Technical Report W1-037/TR1, Environment Agency, Bristol. 118 p.

PEAY S., HILEY P., 2005. Biocide trial to eradicate signal crayfish in the North Esk Catchment. Scottish Natural Heritage Commissioned Report No. 116 (Purchase Order No. 9725).

QUAGLIO F., MALVISI J., MAXIA M., MOROLI C., DELLA ROCCA G., DI SALVO A., 2002. Toxicity of the synthetic pyrethroid ciflutrin to the red swamp crayfish (Procambarus clarkii). Freshwater Crayfish, 13, 431-436.

SANDERS H.O., 1969. Toxicity of pesticides to the crustacean Gammarus lacustris. Technical paper No. 25, U.S. Department of the Interior, Fish and Wildlife Service. Bureau of Sport Fisheries and Wildlife, p. 21.

SAXENA S.C., BAKRA P.P., 1978. Toxicity of pyrethrum to blue rock pigeon. Pyrethrum Post, 14, 47-48.

SIBLEY P.J., 2003. The distribution of crayfish in Britain. In: HOLDICH D.M. and SIBLEY P.J. (Eds.) Management and Conservation of Crayfish. Proceedings of a conference held on 7th November, 2002. Environment Agency, Bristol. 217 p., 64-72. 
